\title{
1. SIDS and environmental governance in the Anthropocene
}

The human race has depended on the environment from the first moment of its existence and, since ancient times, civilizations have both caused and been affected by environmental degradation (Hughes, 2014). Humanity has been guided by and has shaped cultural norms and moral and ethical laws that refer to how to treat the planet or at least their immediate environment. Most of the world religions see humanity's duty of stewardship towards the environment as an "ethical imperative" and encourage stewardship as part of a collective and individual ethical and social response to environmental challenges (Schaefer, 2018). By the nineteenth century already science was addressing the human impacts on natural resources, physical geography and ecosystems (Marsh, 1865). This book is set in the context of the Anthropocene, for some a radical reconceptualization of the relationship between humanity and nature (Baskin, 2015), for others possibly a new geological age (Zalasiewicz et al., 2015). Today, humanity's activities have had irreversible impacts on the environment leading to what can arguably be called the Anthropocene (Grainger, 2017, Zalasiewicz et al., 2017), a new geological epoch characterized by deep and lasting anthropogenic impacts on natural systems which demand societal (Brand, 2016), economic, moral (Lennon, 2017) and political solutions (Pattberg and Zelli, 2016) to the complex environmental crises, spaces and relationships created between human beings (UNESCO, Institute of Development Studies (Brighton, England) \& ISSC, 2016) and between human beings and nature (Hourdequin, 2017) from global (Dryzek, 2016) to local scales (Franchini et al., 2017).

Environmental governance is a multidisciplinary activity that is based on the inherent challenges, conflicts and related dynamics in managing common pool resources (for example oceans, seas, transboundary water courses, the atmosphere and biological diversity) at national and international levels. The good governance of shared resources at risk of environmental degradation because of individual pursuit of gain and where there is no authority or effective authority to ensure sustainability (Ostrom, 2008) is a science (Biermann et al., 2010), an art (Chandler, 2014) and a moral obligation that the present generation has towards itself, to 
future generations, to nature and to its creator (DiMento, 2015). States continue to play a unique role in governing the earth system but the structures of governance have expanded to transcend states to transnational corporations and non-governmental actors that self-regulate and shape norms and standards, inter alia, through certification programmes and industry regulation. Global environmental governance is a response to global environmental challenges that can only be solved by international and public-private coordination.

The livelihoods and economic development of small island developing states (SIDS) are especially dependent on the environment. The global-national-local environmental governance analysis as it applies to small states, however, is largely absent in global environmental governance scholarly literature. This book contributes to the literature on global environmental governance issues at local scales with a particular focus on the SIDS of the Caribbean Community (CARICOM). Caribbean SIDS are a mix of ecosystems, cultures, development characteristics and interactions that in this era of the Anthropocene create unique environmental governance challenges and require solutions that are scale, place and culture appropriate. How do small populations and government administrations manage their global engagement and how do global environmental goals, targets and norms of the Anthropocene translate into local action? Since most studies on global environmental governance focus on large global issues and larger international and global actors, the chapters in this book add to the scholarship by providing insights into a less explored but equal complex area of global environmental governance - namely SIDS and global environmental governance. The CARICOM Caribbean islands that are the subject of this book are quite similar. Together these 15 states are home to approximately 18 million people. They share a history of strong ties of functional cooperation since 1973 when CARICOM created its common market. Today CARICOM operates as a Single Market and Economy (CSME) and cooperates in many areas related to the environment, including trade, education, health, climate change, security and foreign policy.

Understanding complex environmental governance systems is difficult; researchers employ case studies, process tracing, counterfactual analysis, discourse analysis etc. (O’Neill et al., 2013). The book adopts a constructivist approach to norms dynamics in international relations (Finnemore and Sikkink, 1998, 2001) and traces the way that global norms are understood and applied in each of the thematic chapters. It uses discourse from the international and global environmental governance literature to identify and describe the agency (Biermann et al., 2010, Bearce and Bondanella, 2007, Bulkeley, 2005), norms, structures, regimes 
and governance architectures (Biermann et al., 2010, Hearns et al., 2014, Pattberg and Widerberg, 2015, Rochette et al., 2015, Kim, 2013, Lister et al., 2015, Saito-Jensen, 2015) in each of the thematic areas, and their application, interaction, insertion in or rejection by the Caribbean SIDS. The chapters describe how unique historical, cultural and economic contexts have added new levels of complexity to the way global environmental norms, principles, mechanisms and regimes have been deployed or not deployed for Caribbean SIDS. The chapters unearth the ethical dimensions relating for example to the historical responsibility of the global north for environmental degradation and the resulting vulnerability of SIDS in areas such as climate change and shipping pollution. The chapters unearth some of the power asymmetries and complex relationships between new multinational private actors and these SIDS in areas such as natural resource exploitation and tourism. The chapters reflect the optimism and dynamism in new relationships, new policies and the new ways that states and the private sector attempt to implement global environmental norms or to preserve local norms. The examples in the book will be taken from the Caribbean English speaking islands, especially from Jamaica, Barbados, St. Lucia, and Trinidad and Tobago. They share the usual environmental and economic vulnerabilities characteristic of SIDS, but with different economic development trajectories. The first three are heavily reliant on tourism, the latter is an energy-based economy. The environmental governance realities of these states are representative of the entire region, and often reference will be made to the regional governance frameworks of which they - and all other CARICOM states - are a part.

SIDS include 37 developing states, 52 countries and territories, and over 50 million people from the Caribbean, Pacific, Atlantic, Indian Ocean, Mediterranean and South China Sea regions. More than a quarter of the world's countries have a population below 1.5 million, and many of these are islands. Islands form a unique subset of countries, and developing islands in particular share several qualities. Many island cultures see the environment as an integral element of humanity's existence and survival but also struggle with the growing and less positive influences of the Anthropocene (Moore, 2015). Today, for many islands, risk, and environmental risk in particular, has become an integral part of the policy lexicon and of island identity (Malatesta and Schmidt di Friedberg, 2017). SIDS are not a homogeneous group but they do represent a unique group of states in the context of environmental governance because of the multiple challenges to their precarious economic and environmental survival exacerbated by relatively recent socio-ecological and economic transformations (Kuruppu and Willie, 2015, Popke et al., 2016, UNESCO, 2016). They share in common: small land masses, substantial concentration of 
infrastructure and communities in coastal regions that are vulnerable (inter alia) to sea level rise and invasive species, limited financial, technical and human resources, undiversified economies, economic vulnerability and openness to external economic shocks, and limited resilience to frequent extreme climatic events (hurricanes, storm surges, drought). Their small and open economies crumble with a contraction of the global economy or with a fall in local production after a natural disaster (Sanders, 1997). Many islands have substantial debt burdens which limit fiscal and policy space (Alleyne et al., 2014). Public debt in the Caribbean region, for example, was in excess of 76 percent of gross domestic product (GDP), and reached 103 percent of government revenue in Jamaica in 2009. Climate change impacts are an added challenge to already weak economies. SIDS, in spite of these limitations, have been active and engaged in international environmental relations. They were instrumental in the negotiations leading to the United Nations Convention on the Law of the Sea (UNCLOS) Agreement, and were recognized when Jamaica was chosen as the host nation for the signing of the treaty and for the International Seabed Authority of UNCLOS. In 1991, SIDS formed the Alliance of Small Island Developing States (AOSIS): an ad-hoc negotiating and lobbying body of SIDS within the United Nations (UN) to advocate for their environmental concerns especially related to climate change. In 1994, the first United Nations International Conference on Small Island Developing States was held and, since then, every five years, SIDS have met and charted their sustainable development agenda, of which the environment is an integral part. The thematic chapters of this book provide examples of how SIDS have navigated the Anthropocene, being active participants in international environmental institutions, regimes and architectures in the areas of tourism, trade, marine governance, energy governance and heritage preservation.

There are many good texts on environmental governance from global perspectives or northern perspectives. They are helpful to understand global environmental politics and dynamics (Dauvergne, 2005) and earth system dynamics (Biermann and Pattberg, 2012), the environment and nature from different political thought approaches including through the lenses of power and orchestration (Kütting and Lipschutz, 2012) and through ethics and values debates (Gabrielson et al., 2016, Okereke, 2007). Many others address the changing landscape of actors, including the increasing influence of treaty secretariats (Jinnah and Young, 2014), the increasing institutional fragmentation (Zelli and van Asselt, 2013), regime complexes (Keohane and Victor, 2011), the rise of private authority (Green, 2013), transnational corporations (Singh and Bourgouin, 2013) including cities (Papin, 2017) and new partnerships (Mert, 2015) 
and how the changing landscape is impacted upon and impacts regime dynamics, law (May and Daly, 2016, Percival et al., 2014, Bodansky et al., 2007) and new and emerging technologies (Galaz, 2014). Other texts focus on the quality of governance, effectiveness (O'Neill, 2009), compliance (Mitchell, 2009), transparency (Gupta, 2014), participation and agency of actors (Kanie et al., 2013), including citizens (Worthington et al., 2013). Others stress the growing influence of humanity on the environment: the Anthropocene as the new analytical and normative context for functional and global interdependence in international relations (Brown et al., 2018). China and Brazil, Russia, India, China and South Africa (BRICS) have also received a fair share of attention on their impact on global environmental transformations as they relate to environmental governance, especially in relation to carbon emissions and climate change (Zhang and Barr, 2013) as well as on themes related to indigenous peoples and the environment (Castro et al., 2016). Some themes of global relevance and of relevance to developing states, including, for example, environmental justice and participation, have also been dealt with, but few studies are from SIDS' perspectives. There has been recent interest in tourism and sustainability (Mowforth and Munt, 2015), sustainable energy (Vezzoli et al., 2018) as well as on more general governance problems such as corruption and accountability (De Ferranti et al., 2009).

The natural science literature has been thorough on what the environmental risks are for SIDS. The governance literature less so. The natural sciences continue to contribute to our understanding of biodiversity loss (Miloslavich et al., 2010), fisheries depletion (Pinheiro et al., 2015), sea level rise, extreme climatic events and new threats such as plastic pollution (Monteiro et al., 2018). The sociological literature has also addressed the societal impacts from these environmental risks and hazards (Reyer et al., 2015, Forster et al., 2014). Both groups of literature recognize that the Caribbean societies fail to manage or address the risks and hazards as well as they could and that environmental governance is the problem (Scobie, 2012, 2016, Nurse et al., 2014, Fanning et al., 2009, Pittman et al., 2015). But governance has been something of a "black box". This is amazing since SIDS realities are so closely tied to the management of environmental impacts and futures. Global governance looks very different from the perspective of the SIDS; it is almost as if in matters of environmental governance, the international society lives in diverse or different worlds. One world considers that we are past compromising on environmental stewardship for economic reasons and (understandably) need global action to avoid reaching global environmental tipping points (Galaz et al., 2014, Duit et al., 2016, Boas et al., 2016), and the other feels that its hands are tied by limited human, technical and financial resources and struggles 
to find a happy balance between environment and development (Scobie, 2017b, Lucas et al., 2017, Gangopadhyay et al., 2005, Lederer et al., 2018).

Other than very good insights into marine governance (Fanning et al., 2009, Pittman et al., 2015, Turner et al., 2014), the complex issues of environmental governance from an international relations/global political economy perspective are, with a few good exceptions (Turner et al., 2014, Chan and Flanigan, 2017, Scobie, 2012, Pittman et al., 2015, Rochette et al., 2015, Scobie, 2017a), insufficiently addressed in the scholarly literature. This book is designed to fill this gap. The book articulates the issues of global justice, equity, burden sharing, environmental norms, complexity, transformative change, power, scale, resilience, etc. of international relations, international law, international political economy, environmental economics and justice and environmental governance as they relate to SIDS at the theoretical and case study levels. The international relations focus locates SIDS as a subset of developing states with unique sustainable development challenges and specific foreign policy opportunities in environmental inter-state relations. The international political economy focus is used to understand the ways in which governance is driven and environmental impacts are observed within these small developmental states that struggle to balance international norms and obligations with the economic and social development and environmental sustainability in the context of limited technical and administrative public sector resources. The environmental governance perspective allows the text to explore agency, justice and vulnerability; actors, scales and interdependencies; regimes and architectures (broader steering of issues by groups of actors, norms, institutions, etc. (Biermann et al., 2010, Biermann et al., 2009, Hackmann, 2011)) that help define Caribbean environmental governance in the specific area chapters.

Many other texts from the "southern perspectives" are needed if the global environmental literature on the Anthropocene is to be really global in scope. This book is in some measure one of the first to contribute. As such, it is useful for undergraduate and postgraduate students of global governance, environmental studies, international law and development studies, and constructivism. The book is written in a manner accessible to the general reader and this expands the target market well outside universities and colleges. The book will be a good reference text for policy makers, civil society actors, persons within international organizations, environmental practitioners, foreign service officials in permanent missions or visiting SIDS, private sector actors and non-governmental organizations (NGOs) that work with developing states and SIDS. People from the large Caribbean diaspora in North America, Europe and Australia and regions with historical ties to the Caribbean will find the issues familiar 
and the analyses hopefully enlightening. China also has growing interest and investments in the region and some Chinese universities are beginning to do Caribbean Studies but have little SIDS environmental governance literature available. They too should find this book helpful.

This book fills the gap in the international relations literature on environmental governance by systematically answering the following for Caribbean contexts: how are global architectures and norms relevant, absorbed and adapted to local development priorities, norms and architectures in areas such as tourism, marine governance, energy, cultural heritage and trade? To what extent and how are environmental norms and trends imbedded in local contexts? How relevant are national contexts and development trajectories for environmental governance in areas such as sustainable tourism, marine and maritime governance, energy security, cultural heritage and trade? What are the future challenges and outlooks for environmental governance in SIDS? This book answers these questions in seven chapters. Following this chapter, which provides an introduction and a summary of the book, Chapter 2 provides the conceptual and normative context of the volume with its focus on multilevel, polycentric environmental governance: sustainable development, environmental norms, new actors, regions and the special case of SIDS. Thus, Chapter 2 provides the context of environmental governance in the Anthropocene, which has evolved from an inter-state activity to one of global dimensions: actors and forums, regimes and architectures have expanded. It explains five key sets of elements of environmental governance that will be explored in the thematic chapters: contexts and relationships, power, norms and policy, structures and frameworks and quality of governance. It also introduces the concept of complexity as an underlying theme of the book - described to include multiple actors (operating within a framework of multiple forums, complex causalities and conflicting but interrelated agendas) and contested solutions (each with complex forms of implementation, compliance, enforcement and levels of scientific certainty). The chapter also problematizes regional governance. The volume is set in the context of the Caribbean SIDS region, and the section on regional governance presents the relevance and uniqueness of regions as a subset of global environmental governance and how global contexts, agendas and impacts interrelate with regional spaces and actors. The other important thematic element of this chapter is the relevance of "new" actors for SIDS' governance. These include non-state actors, such as the private sector and NGOs, that oftentimes have more resources and capacity to mobilize and influence international and global agendas, standards, norms and public opinion on matters of environmental governance. SIDS are also more mobilized than ever before on environmental governance and in that regard are among the 
"new actors", particularly regarding climate change through the AOSIS. The chapter also helps to set the political context by tracing the evolution of the theme of sustainable development in international environmental policy, particularly with reference to SIDS. The case study methodology chosen for the empirical chapters (Chapters 3 to 8) of this book used data collected from semi-structured interviews with regional and national state and non-state environmental actors (government officials, diplomats, the private sector and NGOs) and supplemented with triangulation (Yin, 2002) from other sources including documents from their organizations and country reports. Chapters 3 to 8 highlight Chapter 2's themes within issue areas of particular importance for Caribbean SIDS: sustainable tourism, climate change, marine and ocean governance, renewable energy and energy security, cultural heritage, and trade. Chapter 9 provides a thematic and analytical summary and highlights linkages with recent research of the environmental governance community.

\section{REFERENCES}

Alleyne, D., Hendrickson, M., Phillips, W., Yoshida, K., Pantin, M. \& Skerrette, N. 2014. Economic Survey of the Caribbean 2013: improved economic performance with reduced downside risks. Studies and Perspectives (The Caribbean) No. 28. Santiago, Chile, United Nations, ECLAC Sub regional headquarters for the Caribbean.

Baskin, J. 2015. Paradigm dressed as epoch: the ideology of the Anthropocene. Environmental Values, 24, 9-29.

Bearce, D. H. \& Bondanella, S. 2007. Intergovernmental organizations, socialization, and member-state interest convergence. International Organization, 61, 703-733.

Biermann, F. \& Pattberg, P. H. 2012. Global Environmental Governance Reconsidered, Cambridge, MA, MIT Press.

Biermann, F., Pattberg, P., Van Asselt, H. \& Zelli, F. 2009. The fragmentation of global governance architectures: a framework for analysis. Global Environmental Politics, 9, 14 40.

Biermann, F., Betsill, M. M., Gupta, J., Kanie, N., Lebel, L., Liverman, D., Schroeder, H., Siebenhüner, B. \& Zondervan, R. 2010. Earth system governance: a research framework. International Environmental Agreements: Politics, Law and Economics, 10 (4), 277-298.

Boas, I., Biermann, F. \& Kanie, N. 2016. Cross-sectoral strategies in global sustainability governance: towards a nexus approach. International Environmental Agreements: Politics, Law and Economics, 16, 449-464.

Bodansky, D., Brunnée, J. \& Hey, E. (eds.) 2007. The Oxford Handbook of International Environmental Law, Oxford, New York, Oxford University Press.

Brand, U. 2016. How to get out of the multiple crisis? Contours of a critical theory of social-ecological transformation. Environmental Values, 25, 503-525.

Brown, C., Eckersley, R. \& Biermann, F. 2018. Global Governance in the "Anthropocene", Oxford, Oxford University Press. 
Bulkeley, H. 2005. Reconfiguring environmental governance: towards a politics of scales and networks. Political Geography, 24, 875-902.

Castro, F. D. E., Hogenboom, B. E. \& Baud, M. E. (eds.) 2016. Environmental Governance in Latin America, Basingstoke, Palgrave Macmillan.

Chan, P. A. \& Flanigan, T. P. 2017. Effective HIV prevention interventions and the need for rapid mobilization to address HIV outbreaks among at-risk populations. Journal of Infectious Diseases, 215, 1491-1492.

Chandler, D. 2014. Beyond neoliberalism: resilience, the new art of governing complexity. Resilience, 2, 47-63.

Dauvergne, P. (ed.) 2005. Handbook of Global Environmental Politics, Cheltenham, UK and Northampton, MA, USA, Edward Elgar Publishing.

De Ferranti, D., Jacinto, J., Ody, A. J. \& Ramshaw, G. 2009. How to Improve Governance: A New Framework for Analysis and Action, Washington, DC, Brookings Institution Press.

DiMento, J. 2015. Laudato si'. Environment: Science and Policy for Sustainable Development, 57, 9-11.

Dryzek, J. S. 2016. Institutions for the Anthropocene: governance in a changing earth system. British Journal of Political Science, 46, 937-956.

Duit, A., Feindt, P. H. \& Meadowcroft, J. 2016. Greening Leviathan: the rise of the environmental state? Environmental Politics, 25, 1-23.

Fanning, L., Mahon, R. \& McConney, P. 2009. Focusing on living marine resource governance: The Caribbean Large Marine Ecosystem and Adjacent Areas Project. Coastal Management, 37, 219-223.

Finnemore, M. \& Sikkink, K. 1998. International norm dynamics and political change. International Organization, 52, 887-917.

Finnemore, M. \& Sikkink, K. 2001. Taking stock: The Constructivist Research Program in International Relations and Comparative Politics. Annual Review of Political Science, 4, 391-416.

Forster, J., Lake, I. R., Watkinson, A. R. \& Gill, J. A. 2014. Marine dependent livelihoods and resilience to environmental change: a case study of Anguilla. Marine Policy, 45, 204-212.

Franchini, M., Viola, E. \& Barros-Platiau, A. N. A. F. 2017. The challenges of the Anthropocene: from international environmental politics to global governance. Ambiente \& Sociedade, 20, 177-202.

Gabrielson, T. E., Hall, C. A. E., Meyer, J. M. E. \& Schlosberg, D. E. (eds.) 2016. The Oxford Handbook of Environmental Political Theory, Oxford, Oxford University Press.

Galaz, V. 2014. Global Environmental Governance, Technology and Politics: The Anthropocene Gap, Cheltenham, UK and Northampton, MA, USA, Edward Elgar Publishing.

Galaz, V., Österblom, H., Bodin, Ö. \& Crona, B. 2014. Global networks and global change-induced tipping points. International Environmental Agreements: Politics, Law and Economics, 16, 189-221.

Gangopadhyay, S., Ramaswami, B. \& Wadhwa, W. 2005. Reducing subsidies on household fuels in India: how will it affect the poor? Energy Policy, 33, 2326-2336.

Grainger, A. 2017. The prospect of global environmental relativities after an Anthropocene tipping point. Forest Policy and Economics, 79, 36-49.

Green, J. F. 2013. Rethinking Private Authority: Agents and Entrepreneurs in Global Environmental Governance, Princeton, NJ, Princeton University Press. 
Gupta, A. 2014. Transparency in Global Environmental Governance: Critical Perspectives, Cambridge, MA, MIT Press.

Hackmann, B. 2011. Analysis of the governance architecture to regulate GHG emissions from international shipping. International Environmental Agreements: Politics, Law and Economics, 12, 85-103.

Hearns, G. S., Henshaw, T. W. \& Paisley, R. K. 2014. Getting what you need: designing institutional architecture for effective governance of international waters. Environmental Development, 11, 98-111.

Hourdequin, M. 2017. Beyond the Anthropocene: perspectives on human-nature relations, old and new. Environmental Values, 26, 263-267.

Hughes, J. D. 2014. Environmental Problems of the Greeks and Romans: Ecology in the Ancient Mediterranean, Baltimore, MD, JHU Press.

Jinnah, S. \& Young, O. R. 2014. Post-treaty Politics: Secretariat Influence in Global Environmental Governance, Cambridge, MA, MIT Press.

Kanie, N., Andresen, S. \& Haas, P. M. 2013. Improving Global Environmental Governance: Best Practices for Architecture and Agency, Abingdon, UK, Routledge.

Keohane, R. O. \& Victor, D. G. 2011. The regime complex for climate change. Perspectives on Politics, 9, 7-23.

Kim, R. E. 2013. The emergent network structure of the multilateral environmental agreement system. Global Environmental Change, 23, 980-991.

Kuruppu, N. \& Willie, R. 2015. Barriers to reducing climate enhanced disaster risks in least developed country-small islands through anticipatory adaptation. Weather and Climate Extremes, 7, 72-83.

Kütting, G. \& Lipschutz, R. 2012. Environmental Governance: Power and Knowledge in a Local-Global World, Abingdon, UK, Routledge.

Lederer, M., Wallbott, L. \& Bauer, S. 2018. Tracing sustainability transformations and drivers of green economy approaches in the global south. The Journal of Environment \& Development, 27, 3-25.

Lennon, M. 2017. Moral-material ontologies of nature conservation: exploring the discord between ecological restoration and novel ecosystems. Environmental Values, 26, 5-29.

Lister, J., Poulsen, R. T. \& Ponte, S. 2015. Orchestrating transnational environmental governance in maritime shipping. Global Environmental Change, 34, $185-195$.

Lucas, H., Fifita, S., Talab, I., Marschel, C. \& Cabeza, L. F. 2017. Critical challenges and capacity building needs for renewable energy deployment in Pacific small island developing states (Pacific SIDS). Renewable Energy, 107, 42-52.

Malatesta, S. \& Schmidt di Friedberg, M. 2017. Environmental policy and climate change vulnerability in the Maldives: from the "lexicon of risk" to social response to change. Island Studies Journal, 12, 53-70.

Marsh, G. P. 1865. Man and Nature, Physical Geography as Modified by Human Action, New York, Charles Scribner.

May, J. R. E. \& Daly, E. E. (eds.) 2016. Environmental Constitutionalism, Cambridge, Cambridge University Press.

Mert, A. 2015. Environmental Governance Through Partnerships: A Discourse Theoretical Study, Cheltenham, UK and Northampton, MA, USA, Edward Elgar Publishing.

Miloslavich, P., Diaz, J. M., Klein, E., Alvarado, J. J., Diaz, C., Gobin, J., EscobarBriones, E., Cruz-Motta, J. J., Weil, E., Cortes, J., Bastidas, A. C., Robertson, 
R., Zapata, F., Martin, A., Castillo, J., Kazandjian, A. \& Ortiz, M. 2010. Marine biodiversity in the Caribbean: regional estimates and distribution patterns. PLoS One, 5, e11916.

Mitchell, R. B. 2009. Regime design matters: intentional oil pollution and treaty compliance. International Organization, 48, 425.

Monteiro, R. C. P., Ivar do Sul, J. A. \& Costa, M. F. 2018. Plastic pollution in islands of the Atlantic Ocean. Environmental Pollution, 238, 103-110.

Moore, A. 2015. Islands of difference: design, urbanism, and sustainable tourism in the Anthropocene Caribbean. Journal of Latin American \& Caribbean Anthropology, 20, 513.

Mowforth, M. \& Munt, I. 2015. Tourism and Sustainability: Development, Globalisation and New Tourism in the Third World, Abingdon, UK, Routledge.

Nurse, L. A., Mclean, R. F., Agard, J., Briguglio, L. P., Duvat-Magnan, V., Pelesikoti, N., Tompkins, E. \& Webb, A. 2014. Small islands. In: Barros, V. R., Field, C. B., Dokken, D. J., Mastrandrea, M. D., Mach, K. J., Bilir, T. E., Chatterjee, M., Ebi, K. L., Estrada, Y. O., Genova, R. C., Girma, B., Kissel, E. S., Levy, A. N., MacCracken, S., Mastrandrea, P. R. \& White, L. L. (eds.) Climate Change 2014: Impacts, Adaptation, and Vulnerability. Part B: Regional Aspects. Contribution of Working Group II to the Fifth Assessment Report of the Intergovernmental Panel of Climate Change, Cambridge, United Kingdom and New York, NY, USA, Cambridge University Press.

Okereke, C. 2007. Global Justice and Neoliberal Environmental Governance: Ethics, Sustainable Development and International Co-operation, Abingdon, UK, Routledge.

O'Neill, K. 2009. The Environment and International Relations, Cambridge, UK, New York, Cambridge University Press.

O’Neill, K., Weinthal, E., Marion Suiseeya, K. R., Bernstein, S., Cohn, A., Stone, M. W. \& Cashore, B. 2013. Methods and global environmental governance. Annual Review of Environment and Resources, 38, 441-471.

Ostrom, E. 2008. The challenge of common-pool resources. Environment: Science and Policy for Sustainable Development, 50, 8-21.

Papin, M. 2017. Global Cities and Climate Change: The Translocal Relations of Environmental Governance, by Lee Taedong Routledge, 2015, 160 pp, £95 hb, ISBN 9780415737371; An Urban Politics of Climate Change: Experimentation and the Governing of Socio-Technical Transitions, by Bulkeley Harriet A., Castán Broto Vanesa \& Edwards Gareth AS Routledge, 2015, 270 pp, $£ 90$ hb, ISBN 9781138791091; The Urban Climate Challenge: Rethinking the Role of Cities in the Global Climate Regime, by Johnson Craig, Toly Noah \& Schroeder Heike (eds) Routledge, 2015, 258 pp, $£ 100$ hb, ISBN 9781138776883. Transnational Environmental Law, 6, 184-187.

Pattberg, P. \& Widerberg, O. 2015. Theorising global environmental governance: key findings and future questions. Millennium: Journal of International Studies, 43, 684-705.

Pattberg, P. \& Zelli, F. 2016. Environmental Politics and Governance in the Anthropocene: Institutions and Legitimacy in a Complex World, Abingdon, UK, Routledge.

Percival, R. V., Lin, J. \& Piermattei, W. 2014. Global Environmental Law at a Crossroads, Cheltenham, UK and Northampton, MA, USA, Edward Elgar Publishing. 
Pinheiro, H. T., Goodbody-Gringley, G., Jessup, M. E., Shepherd, B., Chequer, A. D. \& Rocha, L. A. 2015. Upper and lower mesophotic coral reef fish communities evaluated by underwater visual censuses in two Caribbean locations. Coral Reefs, 35, 139-151.

Pittman, J., Armitage, D., Alexander, S., Campbell, D. \& Alleyne, M. 2015. Governance fit for climate change in a Caribbean coastal-marine context. Marine Policy, 51, 486-498.

Popke, J., Curtis, S. \& Gamble, D. W. 2016. A social justice framing of climate change discourse and policy: adaptation, resilience and vulnerability in a Jamaican agricultural landscape. Geoforum, 73, 70-80.

Reyer, C. P. O., Adams, S., Albrecht, T., Baarsch, F., Boit, A., Canales Trujillo, N., Cartsburg, M., Coumou, D., Eden, A., Fernandes, E., Langerwisch, F., Marcus, R., Mengel, M., Mira-Salama, D., Perette, M., Pereznieto, P., Rammig, A., Reinhardt, J., Robinson, A., Rocha, M., Sakschewski, B., Schaeffer, M., Schleussner, C.-F., Serdeczny, O. \& Thonicke, K. 2015. Climate change impacts in Latin America and the Caribbean and their implications for development. Regional Environmental Change, 17, 1601-1621.

Rochette, J., Billé, R., Molenaar, E. J., Drankier, P. \& Chabason, L. 2015. Regional oceans governance mechanisms: a review. Marine Policy, 60, 9-19.

Saito-Jensen, M. 2015. Theories and Methods for the Study of Multi-level Environmental Governance, Bogor, Indonesia, Center for International Forestry Research (CIFOR).

Sanders, R. M. 1997. The growing vulnerability of small states. The Round Table, $86,361-374$.

Schaefer, J. 2018. Responding to small island nations imperiled by human-forced climate change: an ethical imperative for Christians. Anglican Theological Review, 100, 93-111.

Scobie, M. 2012. Environmental justice and marine governance in the Caribbean. IUCN Academy of Environmental Law eJournal, 1, 30-41.

Scobie, M. 2016. Policy coherence in climate governance in Caribbean small island developing states. Environmental Science \& Policy, 58, 16-28.

Scobie, M. 2017a. Accountability in climate change governance and Caribbean SIDS. Environment, Development and Sustainability, 20, 769-787.

Scobie, M. 2017b. Fossil fuel reform in developing states: the case of Trinidad and Tobago, a petroleum producing small Island developing State. Energy Policy, 104, 265-273.

Singh, J. N. \& Bourgouin, F. 2013. Resource Governance and Developmental States in the Global South: Critical International Political Economy Perspectives, Basingstoke, Palgrave Macmillan.

Turner, R. A., Fitzsimmons, C., Forster, J., Mahon, R., Peterson, A. \& Stead, S. M. 2014. Measuring good governance for complex ecosystems: perceptions of coral reef-dependent communities in the Caribbean. Global Environmental Change, $29,105-117$.

UNESCO 2016. Small Island Developing States - UNESCO's Action Plan. In: D. O. S. P. A. C. B. (ed.) Section on Small Islands and Indigenous Knowledge, Paris: UNESCO.

UNESCO, Institute of Development Studies (Brighton, England) \& ISSC 2016. World Social Science Report 2016. Challenging Inequalities: Pathways to a Just World, Paris, UNESCO Publishing.

Vezzoli, C., Ceschin, F., Osanjo, L., M'Rithaa, M. K., Moalosi, R., Nakazibwe, V. \& 
Diehl, J. C. 2018. Designing Sustainable Energy for All: Sustainable Product-Service System Design Applied to Distributed Renewable Energy, Berlin, Heidelberg, Springer.

Worthington, R., Rask, M. \& Minna, L. 2013. Citizen Participation in Global Environmental Governance, Abingdon, UK, Routledge.

Yin, R. K. 2011. Applications of Case Study Research, Thousand Oaks, CA, Sage.

Zalasiewicz, J., Waters, C. N., Williams, M., Barnosky, A. D., Cearreta, A., Crutzen, P., Ellis, E., Ellis, M. A., Fairchild, I. J. \& Grinevald, J. 2015. When did the Anthropocene begin? A mid-twentieth century boundary level is stratigraphically optimal. Quaternary International, 383, 196-203.

Zalasiewicz, J., Waters, C., Wolfe, A., Barnosky, A., Cearreta, A., Edgeworth, M., Ellis, E., Fairchild, I., Gradstein, F., Grinevald, J., Haff, P., Head, M., Ivar do Sul, J., Jeandel, C., Leinfelder, R., McNeill, J., Oreskes, N., Poirier, C., Revkin, A., Richter, D. D., Steffen, W., Summerhayes, C., Syvitski, J. M., Vidas, D., Wagreich, M., Wing, S. \& Williams, M. 2017. Making the case for a formal Anthropocene epoch: an analysis of ongoing critiques. Newsletters on Stratigraphy, 50, 205-226.

Zelli, F. \& van Asselt, H. 2013. The institutional fragmentation of global environmental governance. Global Environmental Politics, 13 (3), 1-13.

Zhang, J. Y. \& Barr, M. 2013. Green Politics in China: Environmental Governance and State-Society Relations, London, Pluto Press. 